\title{
DEVELOPMENT OF ANAEROBIC DIGESTION OF PALM OIL MILL EFFLUENT WITH HEATED RECYCLE SLUDGE
}

\author{
S. Maulina ${ }^{1,2}$, Irvan ${ }^{1,2, *}$, B. Trisakti ${ }^{1,2}$ and H. Daimon ${ }^{3}$ \\ ${ }^{1}$ Chemical Engineering Department, Universitas Sumatera Utara, Medan, 20155, Indonesia \\ ${ }^{2}$ Sustainable Energy and Biomaterial Center of Excellence, Universitas Sumatera Utara, \\ Medan, 20155, Indonesia \\ ${ }^{3}$ Department of Environmental and Life Sciences, Toyohashi University of Technology, \\ Toyohashi, 441-8580, Japan \\ *E-mail: irvan@usu.ac.id
}

\begin{abstract}
In palm oil production, a factory will also generate various wastes, one of them is a liquid waste in large quantities. This liquid waste is quite harmful to the environment around the mill. Therefore, it is necessary to handle this waste seriously. The purpose of this research is to comparatively determine performance and stability of anaerobic fermentation of palm oil mill effluent with heated recycle sludge at various temperatures i.e. 27 - 28 (room temperature), 70 and $80^{\circ} \mathrm{C}$. Fresh POME of Aceh Tamiang Palm Oil Factory without additional treatment was fed into the bioreactor. A 2 L-continuous mixed tank bioreactor was operated at $55^{\circ} \mathrm{C}$, closed systems, and intermittent. The hydraulic retention time of all experiments was kept at 10 days. The result concluded that heated recycle sludge significantly affected the performance of the bioreactor mainly on biogas production, TS, and VS, VS degradation rate and COD removal. VS degradation rate could be reached to $70 \%$, COD degradation rate of $84 \%$ and 0.78 $\mathrm{NL} /$ day of gas generation at a similar temperature $\left(70^{\circ} \mathrm{C}\right)$ of heated recycle sludge.
\end{abstract}

Keywords: POME, biogas, hydraulic retention time, fermentation, thermophilic

(C) RASĀYAN. All rights reserved

\section{INTRODUCTION}

Palm oil mill effluent (POME), which characterized as concentrated brownish and acidic fluid waste, is the most harmful wastewater for the environment if discharged without treatment ${ }^{1}$. Anaerobic fermentation is believed to be the useful process to treat palm oil mill effluent. Many studies have been carried out with the purpose of controlling the stability and efficiency of the anaerobic process by investigating several parameters such as: recycling the sludge ${ }^{2-6}$, hydraulic retention time ${ }^{7}$, organic loading rate $^{8,9}, \mathrm{pH}^{10}$, trace metals $^{11}$, and nutrient elements ${ }^{12,13}$.

The main problem that is often encountered in anaerobic digestion of POME is scum formation inside the bioreactor. Scum is a layered solid formed from fat contained in POME derived mostly from various saturated fatty acids ${ }^{14}$. Due to the low density, the scum will float on the surface of the liquid within the bioreactor and will prevent biogas to flow up. Although some previous methods have been carried out with continuous stirring whether at mesophilic ${ }^{15-17}$ or at thermophilic conditions but these are considered to be ineffective in eliminating these scum.

Temperature is one of the most significant factors determining the performance and stability of the anaerobic digestion process ${ }^{18,19}$, because it affects both system heating needs and methane generation. This study was carried out to digest POME by utilizing an anaerobic fermenter at $55^{\circ} \mathrm{C}$. The substrate was stirred in the mixing tank with concentrated sludge which earlier stage separated in a settling tank at $70^{\circ} \mathrm{C}$; then the stirred slurry was flown into the anaerobic fermenter. The present paper aims to comparatively evaluate the performance and stability of anaerobic fermentation of palm oil mill effluent with heated recycle sludge at various temperatures $\left(27-28,70\right.$ and $\left.80^{\circ} \mathrm{C}\right)$. The selection of temperatures

Rasayan J. Chem., 11(3), 1151-1158(2018)

http://dx.doi.org/10.31788/RJC.2018.1132096

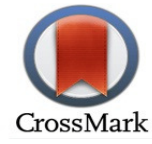


RASĀYAN J. Chem.

Vol. 11 | No. 3 |1151 - 1158 | July - September | 2018

70 and $80^{\circ} \mathrm{C}$ in this study is based on fat pit temperatures at palm oil mills operating around $70-80^{\circ} \mathrm{C}$ and also by considering the melting point of saturated fatty acids ranged from 62.9 to $70.0^{\circ} \mathrm{C}^{14}$.

\section{Material and Methods \\ Sample Characterization}

\section{EXPERIMENTAL}

Fresh POME that serves as a substrate for this study was obtained from palm oil factory's wastewater treatment unit owned by Aceh Tamiang Palm Oil Factory, Nanggroe Aceh Darussalam, Indonesia. This unprepared substrate was then collected in $12 \mathrm{~L}$ uncontaminated vessels and stored at $4.0^{\circ} \mathrm{C}$ freezer until the day of the experiment. While, anaerobically digested wastewater which used as inoculum was collected from the anaerobic lagoon of the same factory. The properties of this substrate are described in Table-1. Table-1 indicates that POME is appropriate for anaerobic fermentation.

Table-1: Fresh Substrate Characterization

\begin{tabular}{l|c}
\hline Parameters & Composition \\
\hline $\mathrm{pH}$ & $4.00-5.00$ \\
\hline $\mathrm{TS}(\mathrm{mg} / \mathrm{L})$ & $58,400-64,800$ \\
\hline $\mathrm{VS}(\mathrm{mg} / \mathrm{L})$ & $48,300-54,000$ \\
\hline $\mathrm{COD}$ Cr $(\mathrm{mg} / \mathrm{L})$ & $53,500-99,500$ \\
\hline $\mathrm{Kj}-\mathrm{N}(\mathrm{mg} / \mathrm{L})$ & $800-1,250$ \\
\hline Fat $(\mathrm{mg} / \mathrm{L})$ & $3,300-9,300$ \\
\hline
\end{tabular}

In this experiment, some auxiliary chemicals were needed to support the digestion process, such as $\mathrm{FeCl}_{2}$ to minimize $\mathrm{H}_{2} \mathrm{~S}$ generation, $\mathrm{NiCl} .6 \mathrm{H}_{2} \mathrm{O}$ and $\mathrm{CoCl}_{2} \cdot 6 \mathrm{H}_{2} \mathrm{O}$ for anaerobic microbial metabolism, and also $\mathrm{NaHCO}_{3}$ was needed to maintain $\mathrm{pH}$ of POME in the bioreactor.

\section{Experimental Procedure}

Schematic view of the experimental set up of an anaerobic bioreactor for the biogas production is demonstrated in Fig.-1. The investigate was carried out using two anaerobic bioreactors, according to the bench scale methane fermentation system, EYELA Model MBF 300M, with a capacity of 5 liters each and utilized with a water jacket, valves, and stirrer. This system was also equipped with a data logger (KEYENCE) to record $\mathrm{pH}$ and temperature values automatically.

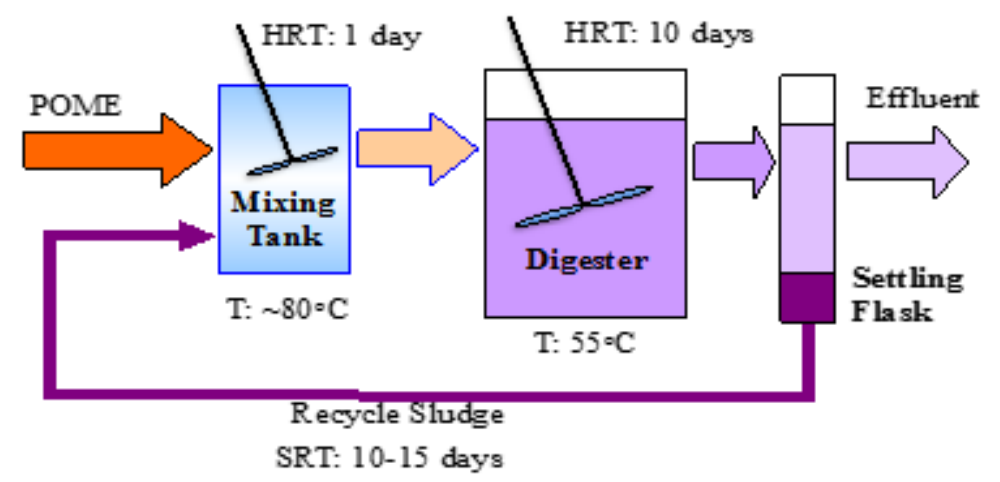

Fig.-1: Schematic View of Anaerobic Bioreactor with the Heated Recycle Sludge

Each liter of fresh POME was supplemented with $2.50 \mathrm{~g} \mathrm{NaHCO}_{3}$ for $\mathrm{pH}$ adjustment and $300 \mu \mathrm{L}$ of a premixed chemical solution $\left(\mathrm{FeCl}_{2}, \mathrm{NiCl} 6 \mathrm{H}_{2} \mathrm{O}\right.$ and $\left.\mathrm{CoCl}_{2} \cdot 6 \mathrm{H}_{2} \mathrm{O}\right)$. This fresh substrate was pumped into the mixing jar every two hours and then mixed with recycling sludge which previously concentrated by settling tank. In mixing tank the mixed waste was heated up to $80^{\circ} \mathrm{C}$ and then pumped into a bioreactor which was maintained at $55^{\circ} \mathrm{C}$. The digested slurry was pumped from the anaerobic bioreactor to the settling tank. At the settling tank, the fermented slurries were separated and pumped back to the mixing 
flask, while the effluent was discharged from the top layer of the settling tank. Fermented slurries were let to gravitate for 360 minutes in a $1 \mathrm{~L}$ volumetric tank as an outside settling tank before $25 \%$ of the digested slurry was sent back to the bioreactor (Fig-2). Settling time of 6 hours was determined by performing the initial experiment, where effluent from the bioreactor was put into a $1 \mathrm{~L}$ volumetric flask. The experimental result to determine settling time is shown in Fig.-3. All graphs of sediment percentage in Fig.-3 start to linear after 6 hours.

Loading up was performed in accordance with the increased generation of biogas that read by using a biogas meter (SHINAGAWA). If biogas generation increased by $20 \%$, then the loading up was improved by $20 \%$ as well, until HRT 10 days was reached and maintained at this value.

Amount of biogas production, $\mathrm{pH}$, recycling and effluent of fermented slurry were analyzed every day. Total solid and M-alkalinity of fermented slurry and volatile solid of the substrate were analyzed every 3 days. The concentration of methane in the biogas was analyzed using a GC (SHIMADZU). TS, VS, Malkalinity, and $\mathrm{pH}$ value were measured in accordance with standards method for the investigation of water and wastewater by American Public Health Association ${ }^{20,22}$.

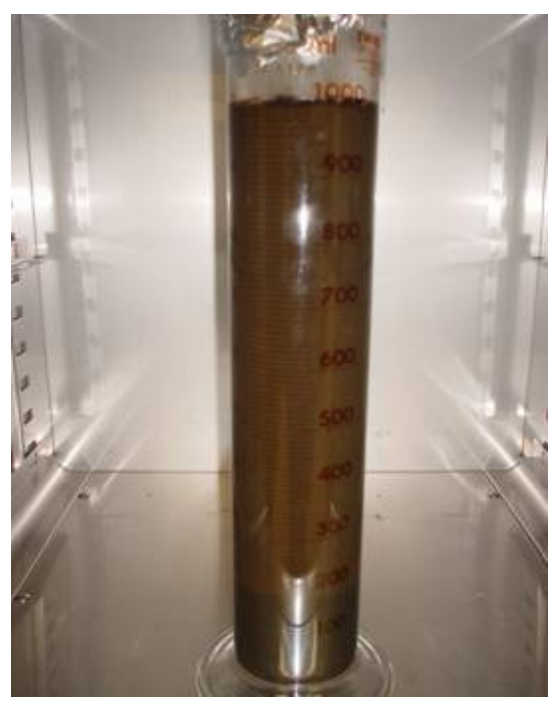

Fig.-2: Sedimentation Process in the Settling Tank after 6 hours

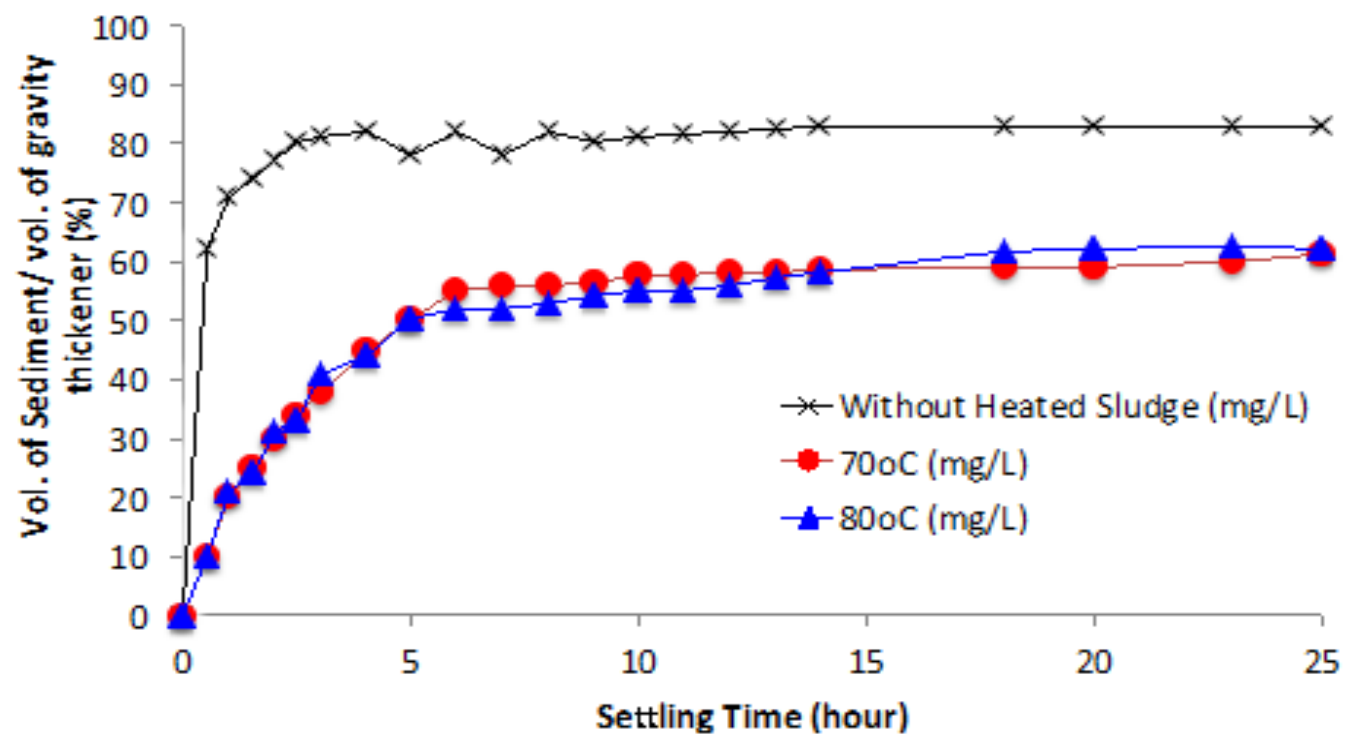

Fig.-3: Initial Experiment Result to Determine Settling Time 


\section{RESULTS AND DISCUSSION}

The anaerobic fermentation performance of palm oil factory effluent with heated recycle sludge was investigated based on the results obtained from the process monitoring. Biogas generation, $\mathrm{pH}, \mathrm{TS}$ and VS were measured every day, while COD, alkalinity, biogas composition were measured every seven days.

\section{Biogas Production in Bioreactor}

Experiment to observe the effect of heated recycle sludge on biogas production was initially conducted by recycling the sludge to mixing tank without heating (Run I), stable data obtained from day 33. Run I ended on the $50^{\text {th }}$ day and subsequently, the temperature at the mixing tank was raised to $80^{\circ} \mathrm{C}$ (Run II). Stable data on Run II began on day 32, and stopped on the $50^{\text {th }}$ day and continued for experiments at temperature $70^{\circ} \mathrm{C}$. Stable data on Run III began on day 30. Fig.-4 demonstrates the biogas generation in the digestion process with heated recycle sludge at various temperatures.

As shown on Fig.-4, the temperature at the mixing tank has a significant effect on biogas generation, where mixing tanks heated at $70^{\circ} \mathrm{C}$ produced higher biogas than without heating. Probably, $70^{\circ} \mathrm{C}$ is the appropriate temperature to effectively mix the saturated fatty acids. However, at $80^{\circ} \mathrm{C}$ biogas production decreased, it is likely that excessive heating caused these fatty acids to evaporate.

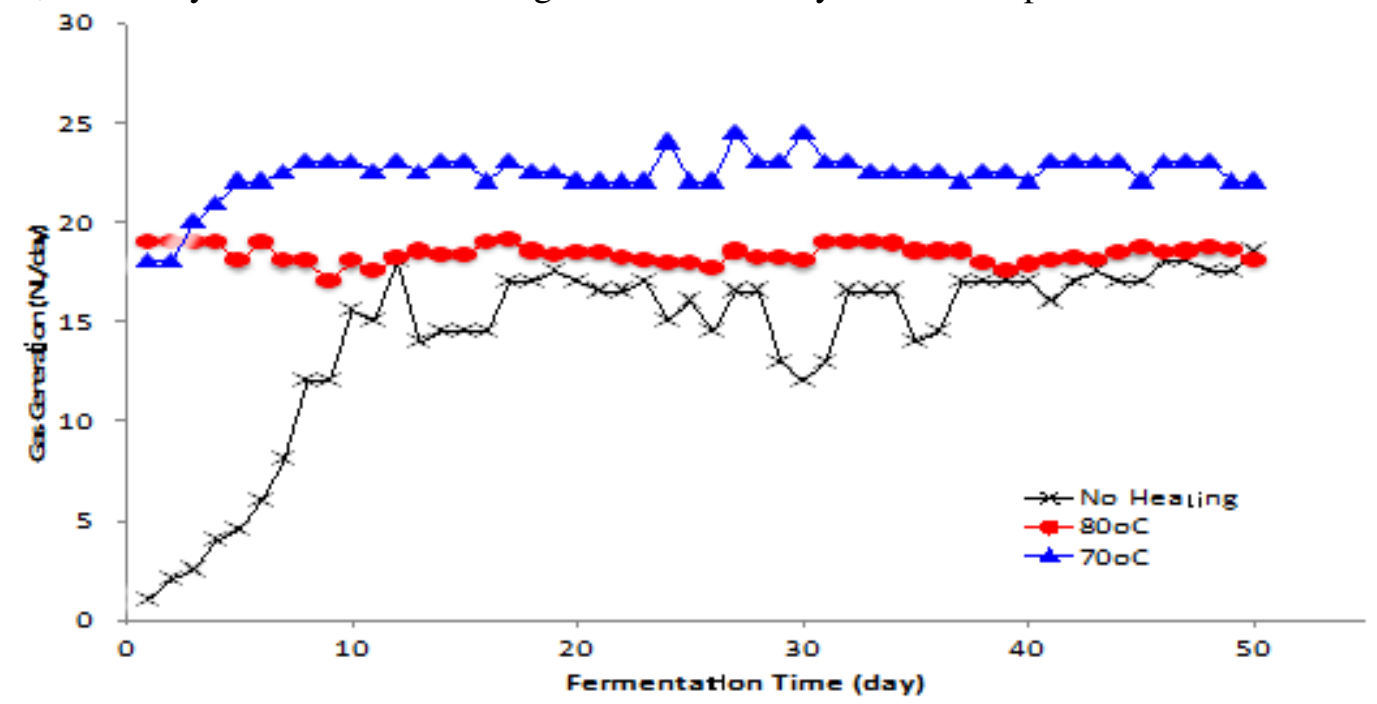

Fig.-4: Biogas Production with Heated Recycle Sludge at Various Temperatures

Measurement of methane content in biogas was conducted at stable data for various temperatures of the heated recycle sludge, the results are shown in Fig.-5.

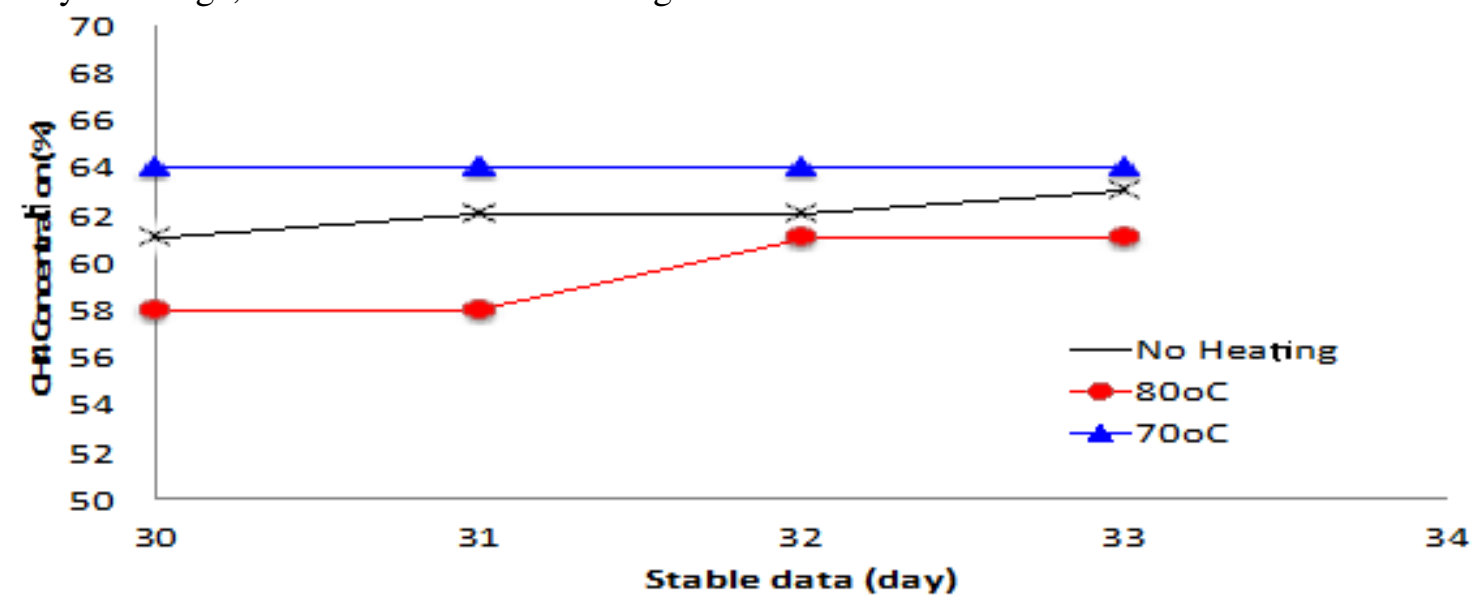

Fig.-5: Methane Content in Biogas Generated at Various Temperatures 
RASĀYAN J. Chem.

Vol. 11 | No. 3 |1151 - 1158 | July - September | 2018

The results show that the productivity of methane varied among the different temperatures. The heated recycle sludge at $70^{\circ} \mathrm{C}$ produced biogas with a methane content that was higher than that produced at $80^{\circ} \mathrm{C}$ and room temperature. According to Choi et al. (2013), the fermentation process of POME could produce biogas with methane concentration may reach in the range 59.5-78.2 \%. From Fig.-5, except the heating of mixing tank at $80^{\circ} \mathrm{C}$, all data of methane content in this experiment are still in that range.

\section{Effect of Heated Recycle Sludge on pH and Alkalinity}

POME obtained from Aceh Tamiang Palm Oil MIll was acidic with $\mathrm{pH}$ ranged 4.0 - 5.0. For effective anaerobic digestion process, $\mathrm{pH}$ values should range between $6.50-7.50 \mathrm{mg} / \mathrm{L}^{20,21}$. In order to maintain to these ranges, an additional substance such as sodium bicarbonate $\left(\mathrm{NaHCO}_{3}\right)$ was put into the bioreactor ${ }^{14}$. In the substrate preparation, $2.50 \mathrm{~g} / \mathrm{l}$ of $\mathrm{NaHCO}_{3}$ was put into the fresh POME. The $\mathrm{pH}$ in the bioreactor of all experiments increased in the range of $7.0-7.5$ from an initial value of 4.0. There is no significant effect of heated recycle sludge on the $\mathrm{pH}$ change in the bioreactor.

Meanwhile, alkalinity values should range between 2,000 to $4,000 \mathrm{mg} / \mathrm{L}^{20}$, for effective anaerobic digestion process, this range is intended to neutralize volatile acids (VS). The effect of heated recycle sludge on M-alkalinity for POME fermentation process is shown in Fig.-6. Similar to the effect on pH, there is no significant effect of heated recycle sludge on alkalinity change, mainly between the heated recycle at 70 and $80^{\circ} \mathrm{C}$. The important thing is alkalinity values are still in the range between the values which still effective for the anaerobic digestion process. As shown in Fig-6 the minimum and the maximum values of alkalinity are 3000 and 4000, respectively.

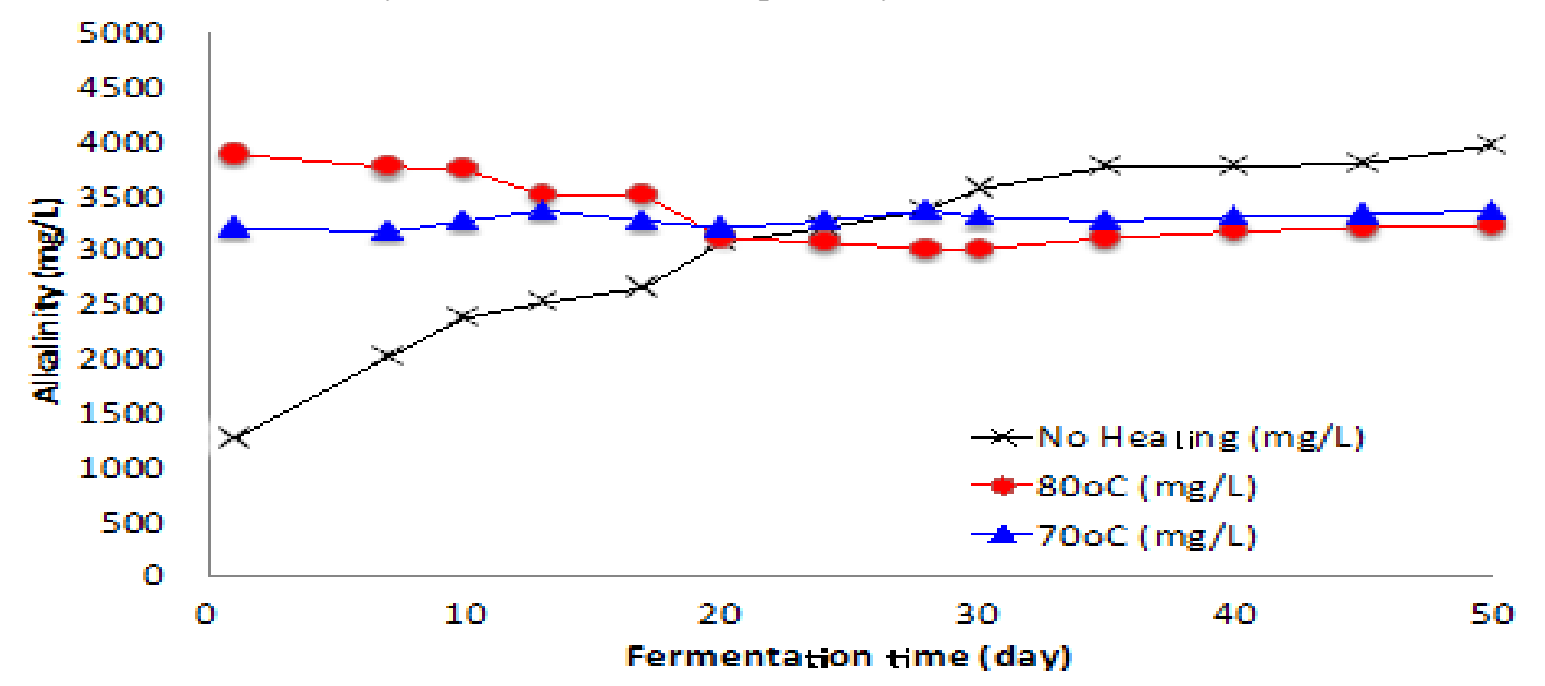

Fig.-6: Effect of Heated Recycle Sludge on Alkalinity

\section{Effect of Heated Recycle Sludge on TS and VS}

Changes in the TS and VS values in the anaerobic digestion process with various heated recycle sludge need to be observed in order to know the performance of microorganism in the different temperature of return sludge. Effect of heated recycle sludge on TS and VS are presented in Fig.-7 and 8. As shown in Fig.-7, total solid of fresh POME reduced significantly from $60,000 \mathrm{mg} / \mathrm{L}$ to values in the range $20,000-$ $40,000 \mathrm{mg} / \mathrm{L}$, this indicates that microorganisms present in the bioreactor worked well to decrease TS at the thermophilic condition. In addition, we can see from Fig-7 that there is a significant effect of heated recycle sludge on TS. Without heating the recycle sludge, TS is in the range 37,000-42,000 mg/L, which is higher than TS with heated sludge. However, if we notice more detail to Fig-7, TS line of heated recycle sludge at $80^{\circ} \mathrm{C}$ is slightly lower than TS line at $70^{\circ} \mathrm{C}$, which means the function of temperature in heated sludge is not clear yet.

A similar trend is also shown in Fig.-8, where volatile solid of fresh POME reduced significantly from $50,000 \mathrm{mg} / \mathrm{L}$ to values in the range $20,000-30,000 \mathrm{mg} / \mathrm{L}$. Here also, we can see from Fig- 8 that, without heating the recycle sludge, VS is in the range of $22,000-30,000 \mathrm{mg} / \mathrm{L}$, which is higher than VS with heated sludge. VS line of heated recycle sludge at $80^{\circ} \mathrm{C}$ is slightly overlapping with VS line at $70^{\circ} \mathrm{C}$. 
RASĀYAN $J$. Chem.

Vol. 11 | No. 3 |1151 - 1158 | July - September | 2018

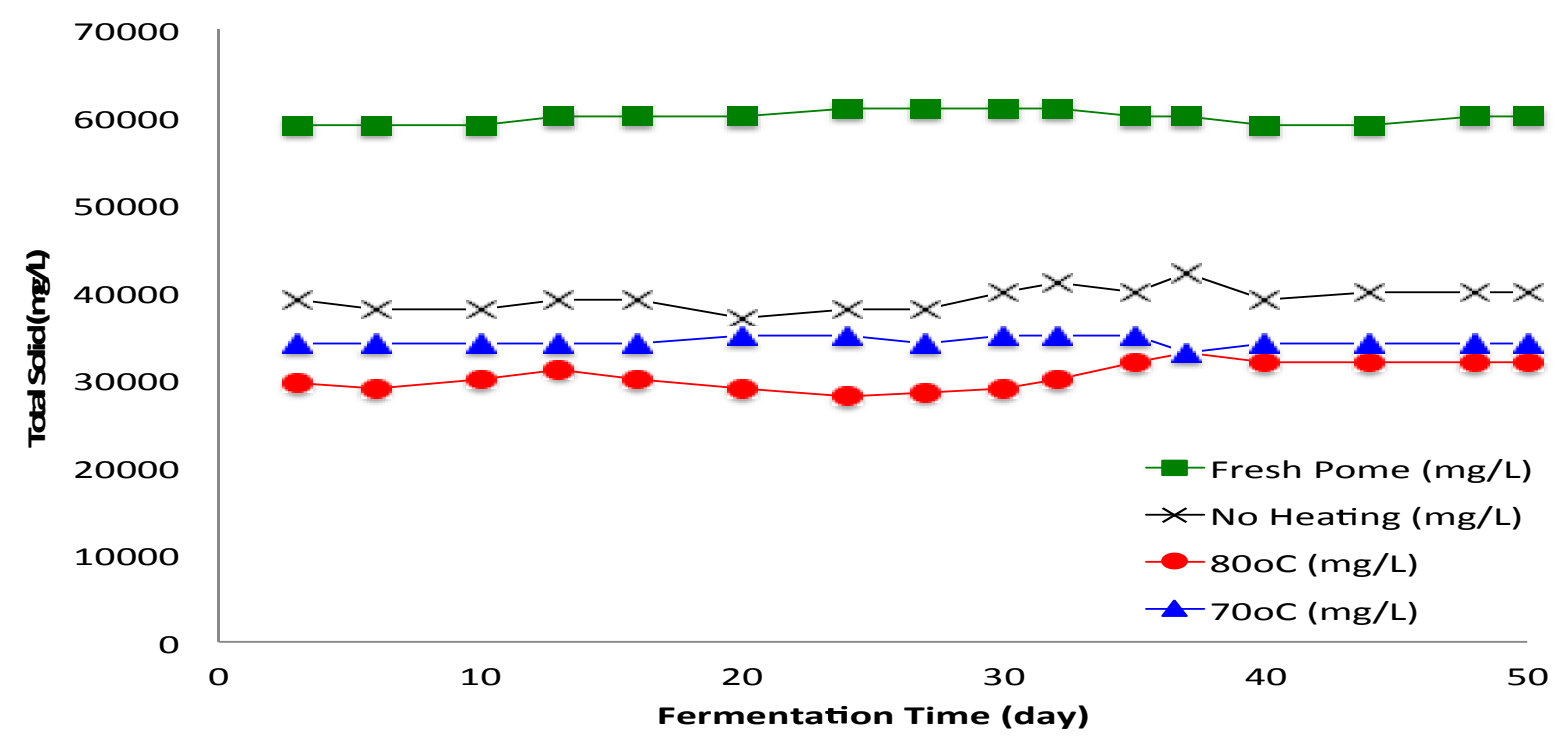

Fig.-7: Effect of Heated Recycle Sludge on TS

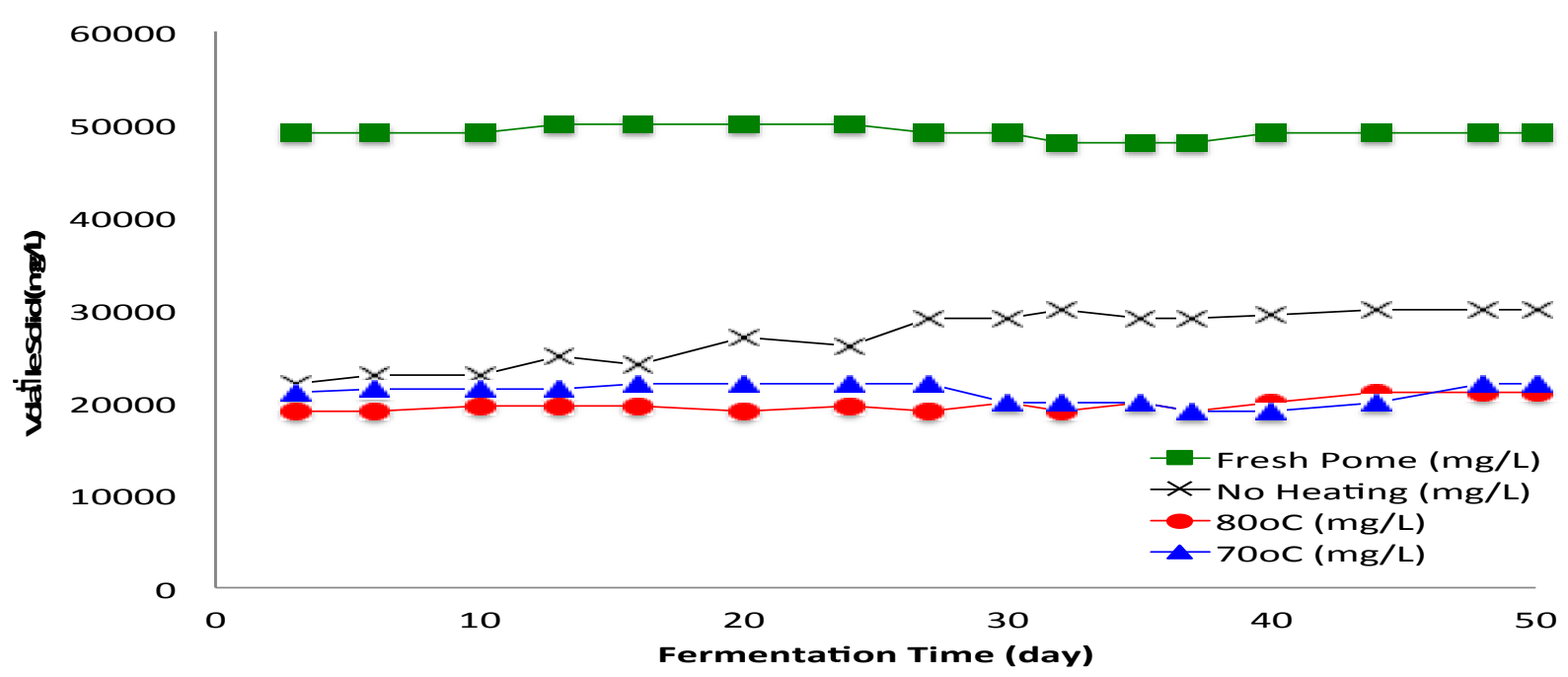

VS Degradation Rate

Fig.-8: Effect of Heated Recycle Sludge on VS

Effect of heated recycle sludge on VS degradation rate is presented in Fig-9. VS degradation rate without heated recycle sludge is in the range of $40-59 \%$, while with heated recycle sludge is in the range of 52 $-65 \%$. It means, the VS degradation rate of the experiment that the sludge recycled with heating $(70-$ $80^{\circ} \mathrm{C}$ ) is higher than the one without heating. The reason for the low degradation rate of recycling sludge with no heating treatment may be attributed to the high content of fat. In heated recycle sludge, it is presumed that fat is easily degraded by dispersion effect of high temperature.

\section{Removal of Chemical Oxygen Demand}

The beneficial influence of the digested sludge in the expressions of chemical oxygen demand was identified. Table-2 demonstrates the performance of POME fermentation to biogas on each experiment. Without heated recycle sludge, the removal efficiency of chemical oxygen demand was $78 \%$, however, with heated recycle, sludge at $80^{\circ} \mathrm{C}$ and $70^{\circ} \mathrm{C}$ were 76 and $84 \%$, respectively. This reveals that the temperature at the mixing tank has a significant effect on COD degradation, where mixing tanks heated at $70^{\circ} \mathrm{C}$ degraded more COD than without heating. The heated recycle sludge can improve the removal of chemical oxygen demand in anaerobic digestion. 


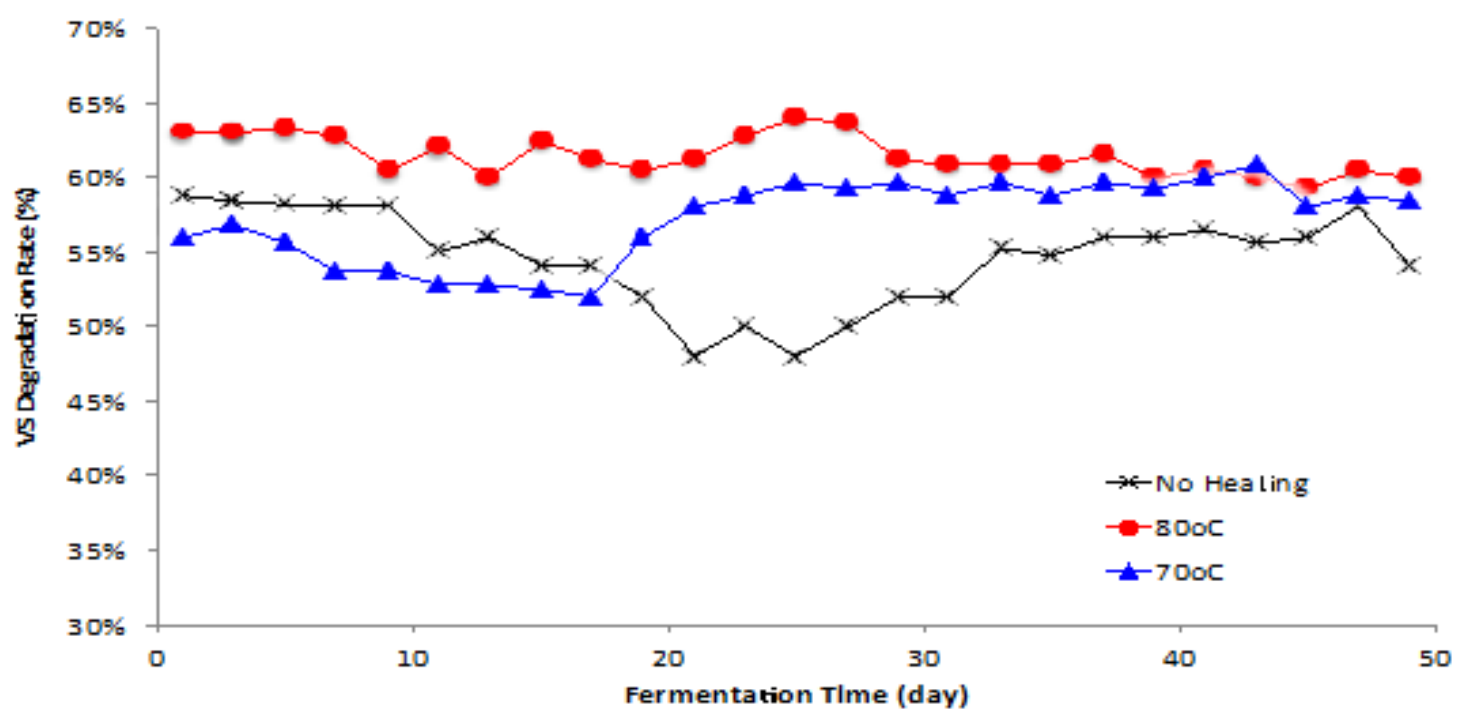

Fig.-9: Effect of Heated Recycle Sludge on VS Degradation Rate

Table-2: Performance of POME Digestion to Biogas on Each Test

\begin{tabular}{|c|c|c|c|c|c|c|c|c|c|}
\hline \multirow{2}{*}{$\begin{array}{l}\text { Mixing } \\
\text { tank } \\
\text { temp. } \\
\left({ }^{\circ} \mathrm{C}\right)\end{array}$} & \multirow[b]{2}{*}{$\begin{array}{l}\text { HRT } \\
\text { (days) }\end{array}$} & \multirow[b]{2}{*}{$\begin{array}{l}\text { SRT } \\
\text { (days) }\end{array}$} & \multicolumn{2}{|l|}{ POME } & \multicolumn{2}{|l|}{ Effluent } & \multirow{2}{*}{$\begin{array}{l}\text { VS } \\
\text { degradation } \\
\text { rate }(\%)\end{array}$} & \multirow{2}{*}{$\begin{array}{l}\text { COD } \\
\text { degradation } \\
\text { rate }(\%)\end{array}$} & \multirow{2}{*}{$\begin{array}{l}\text { Gas } \\
\text { generation } \\
\text { (NL/day) }\end{array}$} \\
\hline & & & $\begin{array}{l}\mathrm{TS} \\
(\mathrm{mg} / \mathrm{L})\end{array}$ & $\begin{array}{l}\text { VS } \\
(\mathrm{mg} / \mathrm{L})\end{array}$ & $\begin{array}{l}\mathrm{TS} \\
(\mathrm{mg} / \mathrm{L})\end{array}$ & $\begin{array}{l}\text { VS } \\
(\mathrm{mg} / \mathrm{L})\end{array}$ & & & \\
\hline $27-28$ & 10 & 15 & 59,900 & 49,200 & 27,900 & 17,200 & 66 & 78 & 0.64 \\
\hline 80 & 10 & 13.2 & 58,900 & 48,400 & 27,500 & 16,200 & 67 & 76 & 0.75 \\
\hline 70 & 10 & 14.6 & 59,850 & 49,210 & 25,100 & 14,500 & 70 & 84 & 0.78 \\
\hline
\end{tabular}

\section{CONCLUSION}

In this study, a high rate of POME decomposition could be achieved by applying the recycle of the waste back to the mixing tank with heating $\left(70\right.$ and $\left.80^{\circ} \mathrm{C}\right)$. This could be done even in a high-speed treatment, which in this case was an HRT of 10 days. This study is quite important in order to apply this process to the industries.

\section{ACKNOWLEDGMENT}

The authors wholeheartedly appreciate Metawater Co. Ltd. - Tokyo.

\section{REFERENCES}

1. P.F. Rupani, R.P. Singh, M.H. Ibrahim, N. Esa, World App. Sci. J., 11(1), 70-81 (2010).

2. T. Setiadi, Husaini, A. Djajadiningrat, Water Sci. Tech., 34, 59-66 (1996), DOI:10.1016/S02731223(96)00821-9

3. M. Faisal, H. Unno, Biochem. Eng. J., 9, 25-31 (2001), DOI: 10.1016/S1369-703X(01)00122-X

4. G.D. Najafpour, A.A.L. Zinatizadeh, A.R. Mohamed, M.H. Isa, H. Nasrollahzadeh, Proc. Biochem., 41, 370-379 (2006), DOI: 10.1016/j.procbio.2005.06.031.

5. Irvan, B. Trisakti, Y. Tomiuchi, U. Harahap, and H. Daimon, IOP Conf. Series: Materials Sci. Eng., 206, 012094 (2017), DOI:10.1088/1757-899X/206/1/012094

6. Irvan, B. Trisakti, S. Maulina and H. Daimon, Oriental J. Chem., 34(1), 161(2018), DOI: 10.13005/ojc/340118.

7. A.A.L. Zinatizadeh, A.R. Mohamed, G.D. Najafpour, M.H. Isa, and H. Nasrollahzadeh, Process Biochem., 41, 1038-1046 (2006), DOI: 10.1016/j.procbio.2005.11.011

8. W. Choorit, P. Wisarnwan, Elec. J. Biotech., 10(3), 376 - 385 (2007), DOI: 10.2225/vol10-issue3fulltext-7

9. Z. Busu, A. Sulaiman, M.A. Hassan, Y. Shirai, S.A. Aziz, S. Yacob, M. Wakisaka, Pertanika J. Trop. Agric. Sci. 33(1), 27-37 (2010). 
RASĀYAN J. Chem.

Vol. 11 | No. 3 |1151 - 1158 | July - September | 2018

10. R. Borja, C.J. Banks, Proc. Biochem. 30(6), 511-521 (1995), DOI: 10.1016/0032-9592(94)00035-2

11. Irvan, Inter. J. Sci. Eng. 3(2), 35-38 (2012), DOI: 10.12777/ijse.3.2.35-38

12. M.A.B. Habib, F.M. Yusoff, K.J. Phang, S. Mohamed, Aquaculture, 158, 95-105 (1997), DOI: 10.1016/S0044-8486(97)00176-2

13. Irvan, B. Trisakti, F. Sosanty, Y. Tomiuchi, Asian J. Chem. 28 377-380 (2016), DOI: 10.14233/ajchem.2016.19353

14. Irvan, IOP Conf. Series: Materials Sci. Eng., 309, 012136 (2018), DOI:10.1088/1757899X/309/1/012136

15. T.O. Peyton, I.W. Cooper, S.K. Quah, Anaerobic digestion of palm oil mill effluent. Proc. $34^{\text {th }}$ Indust.Waste Conf., Purdue University Lafayette, IN. (1979).

16. R. Borja and C.J. Banks, Bioresource Technol. 48, 209-214 (1994), DOI: 10.1016/09608524(94)90148-1

17. K. Wulfert, D. Darnoko, P.L. Tobing, R. Yuliasari, and P. Guritno, International Oil Palm Conference, Nusa Dua, Bali, Indonesia, July 8-12, 265-275 (2002).

18. K.J. Chae, A. Jang, S.K. Yim, and I.S. Kim, Bioresource Technol. 99, 1-6 (2008), DOI: 10.1016/j.biortech.2006.11.063

19. O.A. Arikan, W. Mulbry, S. Lansing, Waste Management, 43, 108-113 (2015), DOI: 10.1016/j.wasman.2015.06.005

20. A.S. Heerah, A. Mudhoo, R. Mohee, S.K. Sharma, Rasayan J. Chem. 1(3). 503-514 (2008).

21. Irvan, B. Trisakti, S. Maulina and H. Daimon, Rasayan J. Chem., 11(1), 378(2018), DOI: 10.13005/ojc/340118.

22. APHA, Standard methods for the examination of water and wastewater, 20th ed. Washington (DC, USA): American Public Health Association, (1998).

[RJC-2096/2018] 